\title{
The Role Of Euros In Eurozone Regionalism And World Globalization
}

Javad Gorjidooz, (Email: Javad.Gorjidooz@erau.edu), Embry-Riddle Aeronautical University

\begin{abstract}
The success of Eurozone regionalism is primarily based on the establishment of regional monetary cooperation that resulted in creation of the Euro. In addition, the development of regional strategies for increasing competitiveness of the region and the establishment of structural funds for assisting economic restructuring, solving the social problems, and reducing the differences in the social economic structure of the member countries helped Eurozone integrates fully with the global economy. Just as the Euro has successfully helped the processes of regionalism (globalization on a smaller scale) in Eurozone, a global currency would be necessary counterpart to the further globalization of world economies. As regional monetary cooperation was required in Eurozone for success of the Euro, a global monetary cooperation is needed for creation and success of a global currency. This paper explores the success of the Euro in Eurozone regionalism, the formation of a global monetary cooperation, development of a framework for currency fluctuations among main currencies (dollar, euro, and yen), and ultimately creation of global currency.
\end{abstract}

\section{INTRODUCTION}

lobalization is not a phenomenon. It is not just some passing trend. It has a technological base and therefore it is here to stay. Globalization has provoked passionate debate about its benefits and costs and raises new legal, economic, and political challenges. Today, globalization is an overshadowing international system shaping the domestic politics and foreign relationship of effectively every country. The focus of this paper is, however, on economic rather than political globalization, although some believe that an economic globalization cannot endure without political globalization. The focal point of this paper is to address what the creation of the Euro did to the success of Eurozone regionalism and to investigate whether creation of a global currency could help the process of globalizing world economies.

The following is the outline of this paper.

- $\quad$ The Concept of Globalization

- $\quad$ Drivers of Globalization

- $\quad$ Benefits and Costs of Globalization

- $\quad$ The Creation of Euro and its Role in Success of Eurozone Regionalism

- $\quad$ Formation of Global Monetary Cooperation and Global Currency

- Conclusion

\section{THE CONCEPT OF GLOBALIZATION}

Not only is world economy being globalized, but the whole world is increasingly behaving as though it were a part of a single market, with interdependent production, consumption of similar goods, and response to the same impulses. Globalization is manifested in the growth of world trade which has exceeded the growth rate of the gross world product (GWP). World trade increased 28 times from 1970 to 2005, whereas gross world production 
increased by about 7 times during the same time period (Hill 2007). The evidence also suggests that foreign direct investment (FDI) is playing an increasing role in the global economy as firms increase their cross-border investment. The average annual outflow of FDI increased from \$25 billion in 1975 to a record high of \$1.3 trillion in 2000, before falling back at $\$ 620$ billion in 2004. It also has resulted in national capital markets becoming increasingly integrated, to the point where some $\$ 1.7$ trillion per day crosses the foreign exchange markets of the world, of which less than $2 \%$ is directly attributable to trade transactions (WTO 2005).

Other features of globalization that are perhaps even more interesting includes the increasing share of consumption of goods that are available from the same companies almost anywhere in the world, and increasingly standardized technology that is used to produce these goods regardless of the location of production. Furthermore, the increasing degree of convergence in economic thinking and technique, and the disappearance of national schools of economic thought, could more aptly be described as the globalization and the homogenization of economics (Hill 2007).

\section{DRIVERS OF GLOBALIZATION}

Three macro factors seem to underlie the trend toward greater globalization: decline in barriers to the free flow of goods, services, and capital; removal of restrictions to foreign direct investment; and technological advancements. The development of technology after the Second World War has contributed significantly to globalization. The costs of transport, travel, and above all the costs of communication and information processing have fallen dramatically due to the progress of technology. There was no fax, no e-mail, nor Internet and no PCs, no satellites, nor cell-phones a half a century ago. Today we witness phenomena that no creative thinker could dream of 50 years ago, such as Indians with a law degree residing in India who earn a living by doing legal case searches for American law firms or Indians with medical degrees residing in Bangalore employed by American doctors to transcribe their tapes overnight. It is clear that the availability of cheap, rapid, and reliable communications permits such phenomena to occur. These drivers of globalizations are the key to the integration of the international capital market, growth of multinational corporations, creation of world market, the spread of consumer knowledge, and ultimately world globalization.

\section{BENEFITS AND COSTS OF GLOBALIZATION}

Globalization certainly permits an increase in the level of global output based on the theory of comparative advantage or the new trade theories. Likewise foreign direct investment brings capital, the best technology, and other forms of intellectual capital, to countries that would otherwise have to do without it, or else invest substantial resources in reinventing the wheel for themselves. It may also bring products that would otherwise be unavailable to the countries where the investment occurs, which presumably increases the quality, and therefore the value, of world output. Additionally, international free flow of capital can transfer savings from countries where the marginal product of capital is low to those where it is high, which again increases world output (Atje 1996 and Haan 2000).

Although there is little reason to doubt that developing countries can expect to benefit from globalization through good use of their abundant resources and access to world-level technology, their long-term economic growth possibilities depend on the increased level of educational standards, ability to apply the technology in their operations, and establishment of institutional arrangements that permit individual pursuit of self-interest or entrepreneurship.

Globalization also is expected to influence the distribution of income among the participating nations. Standard theory would lead one to expect that all countries will benefit from free trade. The trend of economic growth in countries pursuing free trade in the last quarter of century supports this argument. Similarly most FDI goes where a multinational company has intellectual capital that can contribute something to the local economy in forms of increased competition, employment, economic growth, and improved balance of payment. In addition, a flow of capital that finances a real investment is likely to benefit the global company, since the yield on the investment is expected to be higher than the rate of return that it expects to receive at home. Furthermore, the FDI home country would also benefit by creating a demand for export, creating employment, lowering prices for 
consumers, freeing up employees and resources for higher value activities, increasing knowledge from operating in global market, and improving balance of payments by inward flow of foreign earnings. Therefore FDI will be mutually beneficial to investor, home and the host countries.

The effects globalization on domestic income distribution is less clear. Standard theory indicates that trade will tend to hurt unskilled labor in developed countries and to help it in developing countries, since the developing countries will be able to export labor-intensive goods to developed countries, thus increasing the demand for unskilled labor in the developing countries and decreasing it in the developed nations. Therefore, majority of economists seem to agree that the increase in imports of labor-intensive goods has been a major factor in causing the fall in the relative (and sometimes absolute) wages of the unskilled in developed countries and it has been a contributory factor to the increased gap between incomes of rich and poor in these countries (Cline 1997). On the other hand, exports of labor-intensive goods have been a factor in increasing the demand for unskilled labor in developing countries, and therefore helped to equalize the income distribution in those countries. Thus the net effect of globalization on income distribution within countries is mixed. Although, the effect is clear in developing nations, within developed countries it seems to be distinctly ambiguous.

Globalization, of course, is not without a risk. The East Asian and South American financial crises are primarily the result of countries exposing themselves to the full force of the global market before they had built up financial stability for being able to service their debts. Their potential vulnerability due to financial crises discouraged new investors to help stabilize their situations. Moreover, globalization has increased the spread of such insalubrious phenomena as drugs, sex trade, crime, and terrorism (Black and Forbs 2004).

Although globalization has costs and benefits, one cannot reverse the forces of globalization but can seek to maximize the benefits it offers and minimize the risks it creates.

\section{THE CREATION OF EURO AND ITS ROLE IN SUCCESS OF EUROZONE REGIONALISM}

January 1, 1999 marked the first day of a dynamic process that is still unfolding - the implementation of Euro, which is the second largest world currency with potential expansion as new members are added. Euro binds 12 European countries that are members of the European Monetary System (EMS). These countries comprise a region known as Eurozone.

The structure of the Eurozone is designed to implement policies to enable the twelve participating countries to achieve a high degree of convergence while implementing a single monetary policy. This task is to be done by the Eurosystem, comprised of the European Central Bank and the twelve national banks of the member countries.

As these twelve countries unite to achieve a high level of economic growth and stability, the global role of Euro will become even more remarkable. The Euro will have a profound impact on the entire world.

One of the successful approaches implemented in Eurozone regionalism is the development of the regional strategy for cross-border cooperation that shaped the competitiveness of the region. Among the factors contributing to the increase of competitiveness of the individual regions, the Eurozone policy envisions the followings (Gorjidooz 2005):

- Development of scientific and technological activities in the region

- Development of small and medium enterprises

- Development of strategies to attract foreign investment

- Development of physical infrastructure

- Development of human capital

- Development of institutional and social capital 
In addition, to assist in economic restructuring and reducing differences in the social-economic situation of the individual countries, the Eurozone has established the following structural funds (Gorjidooz 2005):

- The European Regional Development Fund which finances structural aid through regional development programs aimed at areas that are in the most unfavorable situation, for the purpose of reducing the socioeconomic differences

- The European Social Fund, which is a major instrument for implementing the Union's social policy, aimed at professional training, requalification, schemes of creating new jobs, etc.

- $\quad$ The European Agricultural Guidance and Guarantee Fund, which provides market support and encourages structural adjustment in the field of agriculture

- $\quad$ The Financial Instrument for Fisheries, which is aimed at supporting the fishery industry.

- $\quad$ The Cohesion Fund

- $\quad$ The European Investment Bank

Therefore the relative success of Eurozone regionalism, on one hand, is based on the regional strategy for cross border cooperation that develops the competitiveness of the region. On the other hand, is based on the Eurozone politicians who undertook structural reforms necessary for Eurozone to integrate fully with the global economy.

\section{FORMATION OF GLOBAL MONETARY COOPERATION AND GLOBAL CURRENCY}

Just as the Euro was one of the major challenges of the late twentieth century, the creation of a global currency will be one of the prime challenges of the twenty-first century. If we were convinced that creation of the Euro helps the globalization of the Eurozone on a small scale, then a global currency would be a necessary counterpart to the further globalization of world economies. As a regional cooperation was required in the Eurozone for success of Euro, a global monetary cooperation is needed to create a global currency. The recent economic crisis in Asia and South America provides a reminder about the harmful consequences of the present shortage of international monetary cooperation.

Since the collapse of the Bretton Woods system, the world monetary system has been torn between two contradictory forces: the free floating exchange rate system and somewhat fixed exchange rate system. The free floating system, which is based on economic liberalism, in theory, provides stability to the world as a whole. In addition, the governments (central banks) are not required continually to maintain exchange rates within specified boundaries and therefore are not forced to engage in implementing intervention policy that may have an unfavorable effect on the economy. Furthermore, in free floating exchange rate system, governments in low interest rate countries are not likely to restrict investors' funds from leaving the country as it is likely under a fixed exchange rate system. Proponents of the somewhat fixed exchange rate system believe that total exchange-rate flexibility is harmful to economic growth and free trade. This belief has provoked the many empirical attempts to stabilize the system and, most important, it has led to the creation of the Euro.

The success of Euro so far and the achievement of healthy economic growth in Eurozone have contributed to the belief that the advent of the Euro creates ideal conditions for reinforcement of global monetary cooperation between the three major currencies (dollar, euro, and yen), and ultimately creation of a global currency. In general, exchange rates exhibit the following three characteristics that make them irreplaceable as tools of international monetary cooperation.

1. They are, by nature, variables of common interest.

2. As relative prices of currencies, they provide reliable confidence indicators for the economic policies carried out in the different currency zones.

3. Exchange rates are valuable signals of economic imbalances.

As Balladur (1999) indicated, "the existence of currency fluctuations should not, in itself, be the subject of concern; rather, it is that fact that (a) these movements are disorderly, (b) all too often - as with yen and dollar in 
1995-96 - they are justified neither by the respective quality of the currencies, nor by the business-cycle timing differences, nor by credible prospects of divergence in budgetary and monetary policies, and they are liable to induce persistent misalignments in the currency markets." Therefore it is crucial to set up a framework for currency fluctuations in order to prevent any disruptive effect on global trade and world economic growth.

This leads to establishment of a system designed at providing greater stability among three major currencies, dollar, euro, and yen. Several alternatives are possible which are based on the link between these currencies and implies an intensive dialogue between US, Eurozone, and Japan authorities.

The most ambitious form of cooperation would be adopting Target Zones. An initial exchange rate would be established for the dollar, euro, and yen. The target zone agreement would specify the fluctuation bands around central rates for theses currencies, which would be regularly adjusted to reflect differentials in inflation and in economic fundamentals. The initial exchange rates would be chosen so as to ensure each economy's internal and external balance. The band should be wide enough to absorb the exchange-rate variations due to short-term economic fluctuations. In addition, it would be made public in order to confine central-bank interventions to situations involving severe imbalances. The central banks would be obligated to intervene at the margins to maintain their currency values within the zones. If the zones are sufficiently wide, central bank intervention would rarely be necessary. However, such wide zones would basically remind you of the current exchange rate system. The ideal target zone allows exchange rates to adjust to economic factors without causing wide swings in international trade and fear in financial markets.

If no consensus emerges on target zones or it seems too difficult to reach at the moment, an alternative international monetary cooperation would be to agree on Reference Parities. Under this agreement, any overstepping of these boundaries would obligate central banks to decide on resolute action without waiting for the next official meeting of the governments or the IMF meeting. This would be a significant step forward from the present arrangement, which requires no consultation. The reference exchange rates would be regularly adjusted to reflect changes in economic fundamentals. The reference parities would be a stepping stone leading to an agreement on target zones.

Therefore, if an agreement materializes on target zones and its implementation is successful, meaning it results in strengthening dramatically the international monetary cooperation, steps can be taken progressively leading to more ambitious solution, a global currency, as mutual confidence develops between G-7 governments.

\section{CONCLUSION}

Since globalization has a technological base, it is therefore here to stay and it is shaping the domestic policies and foreign relations of practically every country. Globalization, through its free trade and foreign direct investment, not only improves economic growth but it also reflects human freedom in economic terms. Therefore globalization, although it could generate social inequalities, provides opportunities to raise the standard of living of all participants in the world trading system. As antitrust laws, the security and exchange commission, the federal trade commission, and countless other agencies and organizations keep America in check, similar transparent mechanisms are needed to make sure globalization is a positive force in the world.

Eurozone, on a modest scale, appears as a successful example of "balanced" globalization by managing increased prosperity while developing cohesion and social inclusiveness. Therefore, as Eurozone can benefit from globalization, the globalization can benefit from Eurozone.

Furthermore, if we are convinced that the creation of the Euro helps the regionalism of the Eurozone, then a global currency would be a necessary counterpart to the further globalization of world economies. As regional cooperation is required in the Eurozone for success of Euro, global monetary cooperation is needed to create a global currency. 
To create a global currency, it is vitally necessary to set up a framework for currency fluctuations among main currencies (dollar, euro, and yen) so that they will no longer exert a disruptive effect on international trade and world economic growth. To achieve this goal, it is necessary to improve the organization of the international monetary system and create currency target zones that allow exchange rates to adjust to economic factors without causing wide swings in international trade and fear in financial markets. As consensus emerges on target zones and the implementation is successful resulting in strengthening dramatically the international monetary cooperation, it may lead to a more ambitious solution, a global currency, as mutual confidence develops among the governments.

\section{BIBLIOGRAPHY}

1. Arora, Ashish and Alfonso Gambardella. 2004. The Globalization of the Software Industry: Perspectives and Opportunities for Developed and Developing Countries. NBER Working Paper \#10538, June.

2. Atje, Raymond and Gary C. Hufbauer. 1996. The Market Structure Benefits of Trade and investment Liberalization. Working Papers on Asia Pacific Economic Cooperation No. 96-7. Washington, D.C.: Institute for International Economics.

3. Balladur, Eduard. 1999. The International Monetary System: Facing the Challenge of Globalization. Presented at the Institute for International Economics, Washington, DC.

4. $\quad$ Barbieri, Katherine. 2002. The Liberal Illusion: Does Trade Promote Peace? Ann Arbor: University of Michigan Press.

5. Berggren, Niclas. 2003. The Benefits of Economic Freedom. The Independent Review 8, no. 2: 193-211.

6. Barro, Robert J. 1994. Economic Growth and Convergence. San Franciso, California, International Center for Economic Growth.

7. Barro, Robert J. and Xavier Sala-I-Martin. 1991. Convergence across States and Regions. Brookings Papers on Economic Activity 1. Washington, D.C.: Brookings Institution.

8. Ben-David, Dan and Michael B. Loewy. 1997. Free Trade, Growth and Convergence. NBER Working Paper No. 6095, July 1997.

9. Bhagwati, Jagdish. 1991. The World Trading System at Risk. London: Harvester and Wheatsheaf.

10. Bhalla, Surjit S. 2002. Imagine There's No Country: Poverty, Inequality, and Growth in the Era of Globalization. Washington, D.C.: Institute for International Economics.

11. Bleany, Michael, and Akira Nishiyama. 2002. Explaining Growth. Journal of Economic Growth 7, no. 1: 43-56.

12. Block, Bill And Kristin Forbes. 2004. Capital Flows to Emerging Markets: The Myths and Realities. Presented at Myths and Realities of Globalization Conference at Federal Reserve Bank of Dallas in November.

13. Bradford Jr., Colin. 1994. From Trade-Driven Growth to Growth-Driven Trade: Reappraising the East Asian Development Experience. Paris: Organization for Economic Cooperation and Development.

14. Cline, William. 1997. Trade and Income Distribution. Washington, D.C.: Institute for International Economics.

15. Collier, Paul, and David Dollar. 2002. Globalization, Growth, and Poverty. New York: Oxford University Press for the World Bank.

16. De Soysa, Indra. 2003. Foreign Direct Investment, Democracy, and Development. London: Routledge.

17. Edwards, Sebastian. 1998. Openness, Productivity, and Growth: What Do We Really Know? Economic Journal 108: 383-98.

18. Frankel, Jeffrey A. 1997. Regional Trading Blocs in the World Economic System. Washington, D.C.: Institute for International Economics.

19. Gorjidooz, Javad. 2003. The Role of Euro in Globalization." Presented at the $78^{\text {th }}$ Annual Conference of Western Economic Association International, July 11-15, Denver, Colorado.

20. _ 2005. The Role of Euro in Regionalism and Globalization. Presented at the Pacific Rim Conference of Western Economic Association International, January 14 - 16, Hong Kong.

21. Haan, Jacob de, and Jan-Egbert Sturm. 2000. On the Relationship Between Economic Freedom and Economic Growth. European Journal of Political Economy 16: 215-41.

22. Hill, Charles, W.L. 2007. International Business: Competing in the Global Marketplace. Fifth Edition, McGraw-Hill, New York. 
23. Hufbauer, Gary C. 1996. World Economic Integration and the Revolution in Information Technology. Technology in Society 18, no.2: 165-172.

24. Karras, Georgios. 1997. Economic Integration and Convergence: Lessons from Asia, Europe and Latin America. Journal of Economic Integration 12, no.4 (December 1997): 1-419-432.

25. Kasper, Wolfgang. 2004.: Freedom and Economic Development: Applying the Lessons. Paper presented at the Mont Pelerin Society Regional Meeting, Sri Lanka, January 10-15.

26. Krueger, Anne O. 1997. The WTO as an International Organization. Chicago: University of Chicago Press.

27. Lindert, Peter H., and Jeffrey G. Williamson. 2001. Does Globalization Make the World More Unequal? National Bureau of Economic Research Working Paper no. 8228. Cambridge, Mass.: National Bureau of Economic Research.

28. Organization for Economic Cooperation and Development (OECD). 2003. The Sources of Economic Growth in OECD Countries. Paris: Organization for Economic Cooperation and Development.

29. Rajapatirana, Sarath. 2004. Trading to Prosperity and Freedom: Developing Countries in PerspectivePaper presented at the Mont Pelerin Society Regional Meeting, Sri Lanka, January 10-15.

30. Rodrik, Dani. 1994. Getting Interventions Right: How South Korea and Taiwan Grew Rich. NBER Working Paper No. 4964. Cambridge, MA: National Bureau of Economic Research, December.

31. _. 1997, Has Globalization gone too far? (Washington: Institute for International Economics).

32. Vanberg, Viktor. 2000. Globalization, Democracy, and Citizens' Sovereignty: Can Competition among Governments Enhance Democracy? Constitutional Political Economy 11, no. 1: 87-112.

33. Weede, Erich. 1996. Economic Development, Social Order, and World Politics. Boulder, Colo.: Lynne Rienner.

34. World Trade Organization. 2005. Data retrieved from WTO website. www.wto.org/english/res_e/statis_e/statis_e.htm.

35. Zdenek Drabek and Sam Laird. (1998) The New Liberalism: Trade Policy Developments in Emerging Markets. Journal of World Trade. 
NOTES 